\title{
THE EMPLOYABILITY OF UNDERGRADUATES IN TAIWAN: FROM THE VIEW POINT OF ENTERPRISES AND THEMSELVES
}

\author{
Jen-Chia Chang ${ }^{1}$, Hsi-Chi Hsiao ${ }^{2}$, Su-Chang Chen ${ }^{3}$, \& Dyi-Cheng Chen ${ }^{4}$ \\ ${ }^{I}$ Graduate Institute of Technological and Vocational Education, National Taipei University of \\ Technology (Taiwan) \\ ${ }^{2}$ Department of Business Administration, Cheng Shiu University (Taiwan) \\ ${ }^{3}$ Department of Marketing and Logistics Management, National Penghu University of Science and \\ Technology (Taiwan) \\ ${ }^{4}$ Department of Industrial Education and Technology, National Changhua University of Education
} (Taiwan)

\begin{abstract}
97.70\% of companies in Taiwan are SMEs. Most of these SMEs have an experience of recruitment on new employees just graduated from universities. Unfortunately, most companies often feel that there were exists a gap between school's supply and company's need for competencies. Therefore, the purpose of this study is to gain an insight into companies' views on the employability of undergraduates and to examine the employability they had by themselves. This study randomly selected 152 employers and 117 employees from 735 SMEs companies in 2018. According to the statistical analysis and discussion, the conclusions and recommendations drawn are as follows: 1. In view of companies' views on employability, employees' "general knowledge" is given greater importance, but graduates focus on "professional skills"; 2. Among the 45 employability items, companies attach the greatest importance to "working under pressure", but graduates focus on "team work"; 3. Top managers attach greater importance to "general knowledge" compared to middle managers; 4. Compared to other countries, the top ten employability items given importance are practically the same, but Taiwan gives special emphasis to learning ability.
\end{abstract}

Keywords: Internship, employability, small and medium-size enterprises (SMEs), undergraduate, cooperative education.

\section{Introduction}

Education provides the different kinds of workforce for economy development. In order to strengthen the employability of undergraduates, the Department of Technological and Vocational Education, MOE proposed the "Outline of Technical and Vocational Education Policy" in March 2017. The outline states that students should strengthen their abilities in practice through systematic internship systems in order for companies to hire graduates best resembling the site of practice (Ministry of Education, 2017). Many studies and graduates have confirmed that the existing school education is not in line with companies' needs and students' career development and there exists a gap between company sites in which students have employed and the company' applications. There also exists a big gap between the abilities that students learn in school and the abilities needed in the actual company workplace. Therefore, the purpose of this study is to gain an insight into employability of graduates from the perspective of enterprises and to find the gap between enterprises and undergraduates. The research conclusions shall serve as a reference for schools when making curriculum adjustments or cultivation of abilities.

\section{The definition and dimensions of employability}

The academia has had divided views on the definition of employability. According to the Business Dictionary (2018), employability could be defined as "A group of essential abilities that involve the development of a knowledge base, expertise level and mindset that is increasingly necessary for success in the modern workplace." It is not easy for us to measure employability, unfortunately, Misra and Mishra (2011) thought employability is not just dependent upon the labor market forces, but also on other factors like willingness, capacity, mobility training (skills enhancement) and functional flexibility (working changing shifts, working beyond job description). For instance, technical universities are 
recognized as the prime engineering who will teach future engineering practitioners and present students with the knowledge on how to become "employable" that is how to develop a range of employability skills which include not only hard skills i.e. discipline specific skills, technical and IT skills but perhaps most importantly soft skills i.e. communication and interpersonal skills, ethics, critical thinking, leadership, entrepreneurship, life-long learning, problem-solving, social responsibility, adaptability, flexibility and others (Chang, et al., 2018). Brennan et al. (2001) conducted a survey on university graduates from 12 countries (now employees). With the assistance of universities, 45,000 new graduates who were already working were surveyed. The questionnaire consists of three dimensions and 37 employability abilities. For the demand in local companies, this study was revised the initial 37-item questionnaire. In this study, a 5-expert pannel discussion meeting was held, and 8 questions were added to make the employability questionnaire become 45 -item questionnaire.

\section{Methodology}

\subsection{Participants}

There were 735 companies in the list of institutions with Top-2000-Company in the Area of Electrical Engineering and Computer Sciences (EECS) of Industry of Manufactures (National Development Council, 2018) were downloaded from the Database of Common Wealth Magazine in Taiwan in 2018. Through purposive sampling, the samples were selected, and the questionnaire was mailed to these institutions. Questionnaires were recovered from 117 companies, accounting for the effective recovery rate of $15.9 \%$.

\subsection{Procedure}

The questionnaire consists of two sections. The first section is about demographic information contains 5 items. The second section consists of 45 items concerning the "Employability". All scales comprised 5-point Likert-type items. The average time for completing each questionnaire is 6-7 minutes.

\subsection{Measurement}

The Employability Scale implemented in this study was initial developed by Brennan, J., Johnston, B., Little, B., Shah, T., \& Woodley, A. (2001). The Employability Scale consists of 3 dimensions: 1. Specific/ professional basic knowledge (SBK), 2. General knowledge/ abilities (GKA), and 3. Behavior/ character / personality (BCP). Internal consistency of total scale is measured with Cronbach's alpha $(\alpha=.974)$, and sub-scale in SBK is .940, in GKA is .937, and in BCP is .961.

\section{Results and discussion}

\subsection{Difference between self and enterprise evaluation on employability}

As shown in Table 1, the self-evaluation employability by graduates is higher than enterprise-evaluation. Furthermore, there is a great difference between them on behavior/character/personality (BCP).

\subsection{Ranking on the employability}

In Table 1, both graduates and enterprises are thought that the employability is insufficient on the specific basic knowledge. The ranking of the respective employability items. The means of the 45 employability items show that "Economic reasoning" has the lowest mean (average=2.72), followed by "Foreign language proficiency (2.78)", and "Understanding complex social systems (2.86)." From the bottom three employability items, it can be found that all of the items fall under SBK, indicating that Taiwanese companies thought their employee with lower specific basic knowledge.

Table 1. Difference between self-evaluation and enterprise- evaluation.

\begin{tabular}{|c|c|c|c|c|c|c|c|}
\hline \multirow{2}{*}{ Item } & \multicolumn{3}{|c|}{ Self-evaluation } & \multicolumn{3}{|c|}{ Enterprise-evaluation } & \multirow{2}{*}{ t-test } \\
\hline & M & SD & Rank & M & SD & Rank & \\
\hline Specific/pro. basic knowledge (SBK) & 3.34 & 1.009 & & 3.22 & $\mathbf{1 . 0 2 2}$ & & $-3.424 *$ \\
\hline 2. Cross-disciplinary thinking/knowledge & 3.49 & 0.988 & 14 & 3.01 & 0.952 & 13 & $-4.037 *$ \\
\hline 3. Field-specific theoretical knowledge & 3.46 & 0.886 & 13 & 3.05 & 1.012 & 14 & $-3.521 *$ \\
\hline 4. Field-specific technical knowledge & 3.50 & 0.847 & 15 & 3.09 & 1.054 & 17 & $-3.439 *$ \\
\hline 7. Computer skills & 3.62 & 1.016 & 19 & 3.55 & 0.941 & 44 & -.579 \\
\hline 8. Understanding complex social systems & 3.07 & 1.120 & 3 & 2.86 & 1.017 & 3 & -1.580 \\
\hline 9. Planning, coordinating and organizing & 3.38 & 0.989 & 8 & 3.05 & 1.032 & 14 & $-2.648 *$ \\
\hline
\end{tabular}




\begin{tabular}{|c|c|c|c|c|c|c|c|}
\hline 10. Applying rules and regulations & 3.20 & 0.949 & 5 & 3.05 & 0.951 & 14 & -1.288 \\
\hline 11. Economic reasoning & 3.04 & 1.094 & 2 & 2.72 & 1.140 & 1 & $-2.315^{*}$ \\
\hline 12. Documenting ideas and information & 3.38 & 0.945 & 8 & 2.93 & 1.021 & 7 & $-3.704 *$ \\
\hline 13. Practical skills in EECS $\#$ & 3.38 & 0.990 & 8 & 2.99 & 1.042 & 12 & $-3.172 *$ \\
\hline 14. Terminology in EECS ${ }^{\#}$ & 3.36 & 1.062 & 7 & 2.97 & 1.038 & 10 & $-3.038 *$ \\
\hline 15. Emergency response $\mathrm{e}^{\#}$ & 3.30 & 1.147 & 6 & 2.95 & 1.060 & 9 & $-2.604 *$ \\
\hline General knowledge \& attitude (GKA) & 3.68 & $\overline{0.933}$ & & 3.25 & 1.038 & & $-4.436^{*}$ \\
\hline 16. Problem-solving ability & 3.69 & 0.960 & 23 & 3.11 & 1.081 & 18 & $-4.634 *$ \\
\hline 17. Analytical competencies & 3.44 & 0.986 & 12 & 2.88 & 1.073 & 4 & $-4.350 *$ \\
\hline 18. Numerical abilities & 3.19 & 1.050 & 4 & 2.89 & 1.007 & 5 & $-2.377 *$ \\
\hline 19. Learning abilities & 3.87 & 0.856 & 38 & 3.63 & 0.975 & 45 & $-2.168 *$ \\
\hline 20. Reflective thinking on one's own work & 3.69 & 0.885 & 23 & 3.26 & 1.002 & 30 & $-3.662 *$ \\
\hline 21. Creativity & 3.56 & 0.986 & 17 & 3.36 & 0.945 & 37 & -1.763 \\
\hline 22. Working under pressure & 3.72 & 0.999 & 27 & 3.20 & 1.088 & 24 & $-3.980 *$ \\
\hline 23. Accuracy, attention to detail & 3.78 & 0.832 & 33 & 3.22 & 1.085 & 25 & $-4.637 *$ \\
\hline 24. Time management & 3.77 & 0.913 & 31 & 3.19 & 1.108 & 23 & $-4.575^{*}$ \\
\hline 25. Negotiating & 3.65 & 0.913 & 20 & 3.14 & 1.061 & 20 & $-4.160 *$ \\
\hline 26. Physical and mental fitness for work & 3.68 & 0.953 & 22 & 3.53 & 1.003 & 43 & -1.304 \\
\hline 27. Manual skills & 3.77 & 0.904 & 31 & 3.36 & 0.973 & 37 & $-3.568 *$ \\
\hline 28. Working independently & 3.86 & 0.937 & 36 & 3.32 & 1.101 & 32 & $-4.257 *$ \\
\hline 29. Ability to work in a team & 3.97 & 0.895 & 41 & 3.50 & 1.042 & 42 & $-3.932 *$ \\
\hline Behavior/character/personality (BCP) & $\mathbf{3 . 8 3}$ & 0.894 & & 3.24 & $\mathbf{1 . 0 4 3}$ & & $-5.769 *$ \\
\hline 30. Initiative & 3.81 & 0.860 & 34 & 3.25 & 1.105 & 28 & $-4.541 *$ \\
\hline 31. Adaptability & 3.91 & 0.857 & 39 & 3.41 & 1.026 & 39 & $-4.253 *$ \\
\hline 32. Decisiveness, persistence & 3.72 & 0.927 & 27 & 3.32 & 1.013 & 32 & $-3.349 *$ \\
\hline 33. Power of concentration & 3.85 & 0.883 & 35 & 3.33 & 1.066 & 35 & $-4.315^{*}$ \\
\hline 34. Getting personally involved & 4.02 & 0.861 & 42 & 3.46 & 0.996 & 41 & $-4.816^{*}$ \\
\hline 35. Loyalty, integrity & 4.07 & 0.858 & 44 & 3.43 & 1.071 & 40 & $-5.237 *$ \\
\hline 36. Critical thinking & 3.70 & 0.874 & 26 & 3.24 & 0.963 & 26 & $-4.020 *$ \\
\hline 37. Oral communication skills & 3.74 & 0.948 & 29 & 3.26 & 1.013 & 30 & $-4.018^{*}$ \\
\hline 38. Written communication skills & 3.66 & 0.921 & 21 & 3.18 & 1.057 & 22 & $-3.852 *$ \\
\hline 39. Tolerance of different view points & 3.94 & 0.884 & 40 & 3.25 & 1.075 & 28 & $-5.632 *$ \\
\hline 40. Leadership & 3.52 & 0.934 & 16 & 2.93 & 1.062 & 7 & $-4.788^{*}$ \\
\hline 41. Taking responsibilities, decisions & 3.69 & 0.942 & 23 & 2.91 & 1.082 & 6 & $-6.232 *$ \\
\hline 42. Tolerance for frustration ${ }^{\#}$ & 3.86 & 0.899 & 36 & 3.11 & 1.052 & 18 & $-6.180 *$ \\
\hline 43. Creative thinking skills ${ }^{\#}$ & 3.74 & 0.902 & 29 & 3.34 & 1.003 & 36 & $-3.455^{*}$ \\
\hline 44. Entrepreneurship\# & 4.03 & 0.825 & 43 & 3.32 & 1.046 & 32 & $-5.980 *$ \\
\hline 45. Empathy & 4.08 & 0.939 & 45 & 3.24 & 1.061 & 26 & $-6.711^{*}$ \\
\hline Whole scale & 3.63 & 0.674 & & 3.17 & 0.838 & & $-4.803 *$ \\
\hline
\end{tabular}

\section{Conclusion and recommendation}

The self-evaluation employability by graduates is higher than enterprise-evaluation. Teachers and students in university could refer the means lower items of employee ability by enterprise evaluation in Table 1 to enforce the skills with remodel curriculum or teaching design.

\section{References}

Brennan, J., Johnston, B., Little, B., Shah, T., and Woodley, A. (2001). The Employment of UK graduates: comparisons with Europe and Japan, Higher Education Funding Council for England.

Business Dictionary. (2018). Definition of employability, Retrieved Aug 26, 2018 from http://www. businessdictionary.com/definition/employability-skills.html.

Jen-Chia Chang, Hsi-Chi Hsiao, Su-Chang Chen, Dyi-Cheng Chen. (2018). The employability of undergraduates in Taiwan: From the view point of enterprises. In Mark Schofield (Chair), International Conference on Education and Learning (ICEL). Symposium conducted at the meeting of the global academic-industrial cooperation society, pp.34-45. Waseda University, Japan. August 22-24, 2018.

Ministry of Education. (2017). Technical and vocational education policy guideline. Retrieved Dec. 20, 2018 from https://ws.moe.edu.tw/001/Upload/3/relfile/6315/52872/d595d36a-1b27-42d3-b50f95c0f4671296.pdf on 1 March 2018.

Misra, K. R. \& Mishra, P. (2011). Employability skills: The conceptual framework \& scale development. The Indian Journal of Industrial Relations, 46 (4), 650-660.

National Development Council, Plate of government opening data: Public information, List of 2016 \& 2017 TTQS Awards. Retrieved from https:// data.gov.tw/dataset/41723 on 28 February 2018. 